\title{
Gambaran Faktor-Faktor Yang Membentuk Persepsi Risiko Keselamatan Pada Pekerja Konstruksi di Proyek Z PT. X
}

\author{
Agra Mohamad Khaliwa ${ }^{1}$, Zulkifli Djunaidi ${ }^{2}$ \\ Magister Keselamatan dan Kesehatan Kerja ${ }^{1}$, Departemen Keselamatan dan Kesehatan Kerja ${ }^{2}$ \\ Fakultas Kesehatan Masyaratakat, Universitas Indonesia \\ agra.mohamad01@ui.ac.id ${ }^{1}$, zul@ui.ac.id ${ }^{2}$
}

\begin{abstract}
Construction has a rapid development for a country. Stated based on the increase in construction growth rate reached $5.76 \%$. It can be said that the construction sector is one of the industries that has a high risk. Most accidents in the construction industry are caused by unsafe behavior, even though there are continuing safety programs. Most of that behavior has the root cause of the inability to identify danger and misperceptions of the risks and the actions they take. This study aims to explain the description of the factors that shape risk perception in the construction workers at Project $X$ of PT. Z with the approach of the Risk-Perceived and the Socio-Cultural Dimension. The method used is semi-quantitative with a cross-sectional study design. The research population consisted of all 44 Project $X$ workers. The frequency distribution of each factor was described univariately in this study; further in-depth analysis would then be carried out. The results show that of the 10 factors which shape Project $X$ workers' risk perceptions still need to be improved, 3 becomes priorities, namely knowledge of risk, control of risk, and common dread. Project $X$ management is expected to raise the risk perception of Project $X$ workers so that they can serve as role models for other workers and prevent workplace accidents.
\end{abstract}

Keywords $\quad$ : Construction Sector, Construction Workers, Risk Perception

\begin{abstract}
ABSTRAK
Konstruksi memiliki perkembangan yang pesat bagi suatu negara. Hal tersebut dapat digambarkan berdasarkan peningkatan laju pertumbuhan konstruksi mencapai 5,76\%. Dapat dikatakan sektor konstruksi merupakan salah satu industri yang memiliki risiko tinggi. Kontribusi kecelakaan di sektor konstruksi banyak disebablan oleh perilaku tidak selamat walaupun sudah ada program keselamatan yang berjalan. Sebagian besar perilaku tidak selamat memiliki akar penyebab ketidakmampuan dalam mengidentifikasi bahaya dan mispresepsi terhadap risiko serta tindakan yang mereka ambil. Penelitian ini bertujuan untuk menjelaskan gambaran faktor-faktor yang membentuk persepsi risiko pada pekerja konstruksi PT.X Proyek Z dengan pendekatan dimensi Risk Perceived dan dimensi sosial budaya. Metode yang digunakan adalah semi-kuantitaif dengan desain studi cross sectional. Populasi penelitian adalah seluruh pekerja Proyek sebanyak 44 orang. Penelitian ini menggunakan analisis univariat untuk menggambarkan distribusi frekuensi masing-masing faktor dan akan dilakukan analisis mendalam dari gambaran distribusi frekuensi. Hasil penelitian menunjukan bahwa dari 10 faktor yang membentuk persepsi risiko pekerja Proyek $\mathrm{Z}$ masih harus ditingkatkan, terdapat 3 faktor yang menjadi prioritas yaitu dengan faktor knowledge of risk, control of risk, dan common dread. Manajemen proyek $\mathrm{Z}$ diharapkan mampu meningkatkan persepsi risiko pekerja proyek $\mathrm{Z}$ agar dapat menjadi role model untuk para pekerja dan mencegah terjadinya kecelakaan kerja.
\end{abstract}

Kata Kunci : Sektor Konstruksi, Pekerja Konstruksi, Persepsi Risiko

\section{PENDAHULUAN}

Konstruksi memiliki perkembangan yang pesat bagi suatu negara. Hal tersebut dapat digambarkan berdasarkan peningkatan laju pertumbuhan konstruksi mencapai 5,76\% (Badan Pusat Statistik,
2020). Selain itu, sektor konstruksi merupakan sektor yang menyerap tenaga kerja dalam jumlah besar. Pada tahun 2018 pekerja tetap dan kontrak mengalami peningkatan sebesar $2,02 \%$ dari tahun sebelumnya dengan total 1.121.092, sedangkan tenaga ahli konstruksi sebanyak 
244.930 (Badan Pusat Statistik, 2019). Namun, perlu diingat karakteristik sektor ini merupakan padat karya dan dinamis. Jika dibandingkan dengan sektor lainnya, konstruksi menyumbang catatan angka kecelakaan yang tinggi, 30\% kecelakaan kerja disumbang dari sektor konstruksi. Dapat dikatakan sektor konstruksi merupakan salah satu industri yang memiliki risiko tinggi (Suparno et al, 2019; Labour department, 2016 dalam Man, S. et al, 2019).

Banyaknya jumlah tenaga kerja pada sektor konstruksi tentu erat terkait dengan perbedaan persepsi atas risiko yang ada. Persepsi risiko dapat didefinisikan sebagai kemampuan dalam menentukan besaran risiko dari suatu bahaya. Sedangkan menurut Sjoberg M (2004) persepsi risiko merupakan penilaian subjektif dari suatu probabilitas kecelakaan yang dapat terjadi dan bagaimana orang peduli terhadap suatu konsekuensi yang ditimbulkan. Persepsi risiko dapat dipengaruhi oleh faktor internal dan eksternal, adapun faktor internal bersumber dari psikologis dan budaya organisasi, sedangkan faktor eksternal dapat bersumber dari iklim keselamatan, tekanan komunitas, serta karakteristik demografi dan pekerjaan. Persepsi risiko sangat berkaitan erat dengan perilaku keselamatan (Chaswa, et al., 2020). Kontribusi kecelakaan di sektor konstruksi banyak disebabkan oleh perilaku tidak selamat walaupun sudah ada program keselamatan yang berjalan. Sebagian besar perilaku tidak selamat memiliki akar penyebab ketidakmampuan dalam mengidentifikasi bahaya dan mispresepsi terhadap risiko serta tindakan yang mereka ambil (Habibnezhad, M., et al., 2016).

Persepsi risiko sendiri memiliki dua sudut pandang secara umum yakni paradigma risk perceived dan paradigma sosial budaya (Loewenstein, 2001). Sudut pandang risk perceived memberikan sudut pandang dari sisi individu tentang bagaimana pekerja melihat risiko dalam sebuah kondisi kerja. Sjoberg menyebutkan 8 kriteria mengenai risk perceived diantaranya, Voluntariness of Risk, Immediacy of Effect, Knowledge of Risk, Control of Risk, Catastrophic Potential, Common Dread, Severity of Consequence (Sjoberg et al, 2004). Pendekatan paradigma sosial budaya dalam persepsi risiko mengkaji bagaimana lingkungan kerja yang dalam hal ini adalah budaya organisasi dan kelompok kerja mempengaruhi persepsi risiko pekerja (Slovic and weber, 2002). Namian (2005) menjelaskan bahwa perlakuan training kepada pekerja berpengaruh untuk meningkatkan keresahan persepsi risiko dari kelompok kerja. Hal ini termasuk peraturan yang berlaku dan keterlibatan seluruh pihak yang akan berpengaruh pada pencatatan perihal keselamatan di tempat kerja termasuk persepsi risiko dari pekerja di proyek (Martin, 2014).

Dari literatur dan teori yang menjelaskan mengenai persepsi risiko, peneliti berfokus untuk menggunakan paradigma risk perceived dan sosial budaya dalam meneliti persepsi pekerja di proyek konstruksi. Variabel yang dibahas pada pendekatan risk perceived adalah faktor voluntariness of risk, immediacy of effect, knowledge of risk, control of risk, catastrophic potential, common dread, severity of consequences, dan pendekatan sosial budaya akan membahas faktor training, regulatory, dan organization.

Tujuan dari penelitian ini akan menggambarkan hasil analisis dari pendekatan dimensi risk perceived dan sosial budaya. Hasil analisis akan menggambarkan profil persepsi risiko Proyek Z PT. X yang dideskripsikan menggunakan tabel deskripsi dan diagram jaring. Penelitian ini diharapkan mampu digunakan sebagai acuan untuk mengembangkan program peningkatan persepsi risiko Proyek Z PT. X dan acuan untuk meneliti persepsi risiko keselamatan pada proyek konstruksi lainnya.

\section{METODE}


Penelitian ini merupakan penelitian semi-kuantitatif dengan menggunakan desain studi cross sectional. Populasi yang digunakan dalam penelitian ini adalah seluruh pekerja (44 orang) pada Proyek Z PT X. Penelitian ini menggunakan kuesioner yang disebar pada 26 April 2021, kuesioner yang digunakan merupakan hasil pengembangan dari Faktor yang membentuk persepsi risiko keselamatan yang telah dilakukan pada penelitian lain sehingga didapatkan 10 faktor terfokus yang digunakan sebagai basis penelitian ini. Kuesioner telah melewati test validitas dan reliabilitas menggunakan SPSS dan telah dinyatakan valid dan reliable. Responden mengisi kuesioner dengan skala likert dari 1 sampai 4, (1=Sangat tidak setuju, 2= Tidak setuju, $3=$ Setuju, $4=$ Sangat setuju) untuk masing masing variable. Analisis data dilakukan secara univariat untuk mengetahui gambaran masing-masing variable yang diteliti dan kemudian diperkuat dengan analisis menggunakan data perusahaan dan observasi lapangan. Data yang dianalisis selanjutnya akan disajikan dalam bentuk tabel untuk memberikan gambaran distribusi frekuensi Faktor yang mempengaruhi persepsi risiko keselamatan menggunakan SPSS Versi 25.

\section{HASIL}

Tabel 1. Hasil Analisis Univariat Karakteristik Demografi Repsonden

\begin{tabular}{lcc}
\hline \multicolumn{1}{c}{$\begin{array}{c}\text { Karakteristik } \\
\text { Demografi }\end{array}$} & N & $(\boldsymbol{\%})$ \\
\hline $\begin{array}{l}\text { Jenis Kelamin } \\
\text { Laki-Laki } \\
\text { Perempuan }\end{array}$ & 44 & 100 \\
\hline Usia & 0 & 0 \\
$\leq \mathbf{3 0}$ & 19 & 43 \\
$\mathbf{3 1}$ & 25 & 57 \\
\hline Lama Kerja & 30 & 68 \\
1-3 Bulan & 14 & 32 \\
\hline 3-6 Bulan & \\
\hline
\end{tabular}

Hasil distribusi karakteristik frekuensi demografi responden (Tabel 1) menunjukan bahwa seluru responden adalah laki-laki (100\%), dengan distribusi usia $\leq 30$ tahun sebanyak 19 orang (43\%) dan pekerja dengan usia $\geq 31$ tahun sebanyak 25 orang (57\%). Sebaran lama kerja untuk pekerja di Proyek $\mathrm{Z}$ didapatkan bahwa pekerja yang bekerja 1-3 bulan ada sebanyak 30 orang (68\%) dan pekerja yang bekerja selama 3-6 bulan ada sebanyak 14 orang (32\%). Distribusi ini terjadi dikarenakan proyek $\mathrm{Z}$ adalah proyek yang baru berjalan selama 6 bulan dan telah terjadi beberapa kali perubahan formasi pekerja.

$\begin{array}{llr}\text { Tabel } & \begin{array}{l}\text { 2. Distribusi } \\ \text { Pemahaman } \\ \text { Terkait } \text { Training }\end{array} & \begin{array}{r}\text { Frekuensi } \\ \text { Responden }\end{array} \\ & \end{array}$

\begin{tabular}{lcc}
\hline \multicolumn{1}{c}{ Training } & N & $(\%)$ \\
\hline $\begin{array}{l}\text { Training Kurang } \\
\text { Penting } \\
\text { Training Penting }\end{array}$ & 22 & 50 \\
\hline
\end{tabular}

Tabel 2 menjelaskan bahwa pemahaman pekerja Proyek Z PT. X terkait training, terdapat 22 orang (50\%) yang menganggap training adalah hal yang kurang penting, sedangkan didapatkan 22 orang (50\%) menganggap bahwa training merupakan hal yang penting.

Tabel 3. Distribusi Frekuensi Pemahaman Responden terhadap Regulatory (Peraturan) terkait safety yang berlaku di PT. $X$

\begin{tabular}{lcc}
\hline \multicolumn{1}{c}{ Faktor Regulatory } & N & $(\%)$ \\
\hline Kurang Baik & 24 & 55 \\
Baik & 20 & 45 \\
\hline
\end{tabular}

Tabel 3 menjelaskan bahwa pemahaman pekerja Proyek Z PT. X terkait peraturan terkait safety yang berlaku di PT.X, terdapat 24 orang (55\%) yang masih kurang baik pemahamannya, 
dan didapatkan 20 orang (45\%) yang sudah baik pemahamannya.

Tabel 4. Distribusi Frekuensi Pemahaman Responden Terhadap Peran Organisasi

\begin{tabular}{lcc}
\hline \multicolumn{1}{c}{ Faktor Organisasi } & N & $(\%)$ \\
\hline Kurang Baik & 24 & 55 \\
Baik & 20 & 45
\end{tabular}

Tabel 4 menjelaskan bahwa pemahaman pekerja Proyek Z PT. X terkait peran organisasi terdapat 24 orang $(55 \%)$ yang masih kurang baik pemahamannya terhadap peran yang dilakukan oleh organisasi, dan 20 orang (45\%) yang sudah baik pemahamannya

Tabel 5. Distribusi Frekuensi Tingkat Voluntariness of Risk Responden terhadap Risiko

\begin{tabular}{lcc}
\hline $\begin{array}{c}\text { Tingkat Voluntariness } \\
\text { of Risk }\end{array}$ & N & $(\%)$ \\
\hline Terpaksa & 29 & 66 \\
Sukarela & 15 & 34 \\
\hline
\end{tabular}

Tabel 5 menjelaskan bahwa terdapat 29 orang $(66 \%)$ dari pekerja Proyek Z yang merasa terpaksa untuk menerima risiko yang ada pada pekerjaan, dan didapatkan 15 orang (34\%) pekerja proyek $\mathrm{Z}$ merasa sukarela terhadap risiko yang ada pada pekerjaan.

Tabel 6. Distribusi Frekuensi Tingkat Immediacy of Effect Yang Dirasakan Oleh Responden

\begin{tabular}{lcc}
\hline $\begin{array}{c}\text { Tingkat Immediacy of } \\
\text { Effect }\end{array}$ & $\mathbf{N}$ & $\mathbf{( \% )}$ \\
\hline Tidak Langsung & 29 & 66 \\
Langsung & 15 & 34 \\
\hline
\end{tabular}

Tabel 6 menjelaskan bahwa terdapat 29 orang $(66 \%)$ dari pekerja Proyek Z yang merasa bahwa suatu risiko tidak menyebabkan efek langsung, sedangkan didapatkan 15 orang (34\%) pekerja Proyek $\mathrm{Z}$ yang merasa bahwa suatu risiko bisa menyebabkan efek langsung.

Tabel 7. Distribusi Frekuensi Tingkat Knowledge of Risk Oleh Responden

\begin{tabular}{lll}
\hline $\begin{array}{c}\text { Tingkat Knowledge of } \\
\text { Risk }\end{array}$ & N & (\%) \\
\hline Kurang baik & 33 & 75 \\
Baik & 11 & 25
\end{tabular}

Tabel 7 menjelaskan bahwa terdapat 33 orang $(75 \%)$ dari pekerja Proyek Z memiliki pengetahuan yang kurang baik terhadap risiko, sedangkan didapatkan didapatkan 11 orang (25\%) pekerja Proyek $\mathrm{Z}$ yang sudah baik pengetahuannya terhadap risiko.

Tabel 8. Distribusi Frekuensi Tingkat Control of Risk Oleh Responden

\begin{tabular}{lcc}
\hline $\begin{array}{c}\text { Tingkat Control of } \\
\text { Risk }\end{array}$ & N & (\%) \\
\hline Kurang baik & 35 & 79,5 \\
Baik & 9 & 20,5 \\
\hline
\end{tabular}

Tabel 8 menjelaskan bahwa terdapat 35 orang $(79,5 \%)$ dari pekerja Proyek Z kurang baik dalam pengendalian risiko, sedangkan didapatkan didapatkan 9 orang $(20,5 \%)$ pekerja Proyek $\mathrm{Z}$ yang bisa melakukan control terhadap pengendalian risiko.

Tabel 9. Distribusi Frekuensi Catastrophic Potential Oleh Responden

\begin{tabular}{lcc}
\hline \multicolumn{1}{c}{ Catasthropic Potential } & N & $(\boldsymbol{\%})$ \\
\hline Katastropik & 30 & 68 \\
Kronik & 14 & 32 \\
\hline
\end{tabular}

Tabel 9 menjelaskan bahwa terdapat 30 orang $(68 \%)$ dari pekerja Proyek $\mathrm{Z}$ menilai dampak dari suatu risiko bersifat 
katastropik, sedangkan didapatkan didapatkan 14 orang (32\%) pekerja Proyek $\mathrm{Z}$ menilai dampak dari suatu risiko bersifat kronik.

Tabel 10. Distribusi Frekuensi Common Dread Oleh Responden

\begin{tabular}{lcc}
\hline \multicolumn{1}{c}{ Common Dread } & N & $(\%)$ \\
\hline Tidak takut & 32 & 73 \\
Takut & 12 & 27 \\
\hline
\end{tabular}

Tabel 10 menjelaskan bahwa terdapat 32 orang $(73 \%)$ dari pekerja Proyek $\mathrm{Z}$ tidak takut dalam menghadapi risiko yang ada pada pekerjaan, sedangkan didapatkan didapatkan 12 orang $(27 \%)$ pekerja Proyek Z takut dalam menghadapi risiko yang ada pada pekerjaan.

Tabel 11. Distribusi Frekuensi Severity of Consequences Oleh Responden

\begin{tabular}{lcc}
\hline $\begin{array}{c}\text { Severity of } \\
\text { Consequences }\end{array}$ & $\mathbf{N}$ & $(\%)$ \\
\hline Kurang Fatal & 25 & 57 \\
Fatal & 19 & 43 \\
\hline
\end{tabular}

Tabel 11 menjelaskan bahwa terdapat 25 orang $(57 \%)$ dari pekerja Proyek $\mathrm{Z}$ merasa konsekuensi dari suatu risiko bersifat kurang fatal, sedangkan didapatkan didapatkan 19 orang (43\%) pekerja Proyek Z merasa konsekuensi dari suatu risiko bersifat fatal.

\section{PEMBAHASAN}

\section{Analisis Hasil Distribusi Frekuensi Responden pada Faktor Training}

Hasil penelitian menjelaskan bahwa pekerja Proyek Z PT. X masih melihat training kurang penting. Hal ini dapat ditandai dari masih $50 \%$ pekerja menilai bahwa training kurang penting. Analisis ini diperkuat dari hasil telaah dokumen bahwa sebenarnya PT. X telah memiliki departemen yang berfokus pada pelaksanaan training termasuk pelaksanaan rencana training safety kepada seluruh pekerja PT. X namun, dalam pelaksanaannya di Proyek Z sudah ada perencanaan terkait training untuk pekerja. Akan tetapi, kendala yang terjadi adalah masalah kualitas training seperti jadwal, pelatih, dan angka turnover pekerja yang tinggi sehingga menyebabkan masih adanya persepsi yang melihat bahwa training kurang penting bagi pekerja. Hal strategis yang dapat dilakukan adalah mengatur jadwal refreshment pelatihan bagi pekerja dan monitoring kebutuhan bagi pekerja yang masih baru masuk ke Proyek Z, PT. X.

Secara garis besar, dari hasil distribusi responden yang melihat pentingnya training dapat dikatakan seimbang. Hal yang perlu diperhatikan adalah pengembangan metode training sebagai langkah untuk mengembangkan kualitas pekerja sebagaimana dijelaskan oleh Namian (2016) bahwa metode training yang baik adalah ketika terdapat expert yang dapat membangun interaksi langsung dengan peserta dan pelaksanaan training dilaksanakan di on-site. Diharapkan poinpoin tersebut dapat meningkatkan hasil kualitas training yang dapat diterima oleh pekerja dan diadakannya pelaksanaan berkala pelatihan sesuai dengan kebutuhan lapangan.

\section{Analisis Hasil Distribusi Frekuensi Responden pada Faktor Regulatory}

Hasil penelitian menjelaskan bahwa distribusi persepsi risiko terkait faktor regulatory masih lebih banyak yang kurang baik (55\%) dibanding yang sudah baik (45\%). Tingginya angka tersebut, dipengaruhi oleh faktor turnover pekerja yang tinggi sehingga perlu ada pengulangan sosialisasi pemahaman peraturan dengan metode-metode lain seperti menyelipkan konten terkait prosedur atau peraturan pada momen safety talk setiap seminggu sekali. Alomari et al (2018) menjelaskan bahwa faktor peraturan terkait safety akan mempengaruhi persepsi pekerja. Karena 
itu, peningkatan pemahaman terkait prosedur keselamatan harus melibatkan banyak pihak yang terlibat (Lewis, 2003). Dari hasil telaah dokumen, PT.X telah memiliki prosedur keselamatan, seperti kebijakan yang ditandatangani oleh presiden direktur, manual sistem manajemen K3, HSE Plan, dan prosedur teknis seperti surat izin kerja atau LOTO. Namun, poin penting dalam penyampaian prosedur keselamatan di lapangan adalah HSE proyek harus dapat mengkomunikasikan peraturan tidak hanya melalui induction yang terjadwal tapi melalui media-media kampanye langsung seperti HSE board atau memberikan poster-poster yang berkaitan dengan prosedur di tempat dimana pekerja proyek biasa beristirahat. Keterlibatan manajemen puncak saat melakukan kunjungan manajemen untuk mengingatkan pelaksanaan prosedur juga menjadi salah satu faktor yang akan memberikan pekerja tentang pentingnya memahami keselamatan dan secara sejalan akan meningkatkan persepsi risiko keselamatan pekerja.

\section{Analisis Hasil Distribusi Frekuensi Responden pada Faktor Organization}

Hasil penelitian menjelaskan bahwa masih lebih banyak pekerja yang melihat peran organisasi kurang baik $(55 \%)$ dibanding yang sudah baik (45\%). Hal ini terjadi dikarenakan faktor yang sama yakni penerapan komunikasi, penghargaan, dan juga sanksi yang belum menyentuh pekerja secara menyeluruh. Namun, lagi-lagi faktor turnover pekerja yang tinggi juga menjadi faktor penyebab terjadinya hal ini, Alomari et al., (2018) menjelaskan bahwa faktor organisasi seperti komitmen management, penerapan program terkait safety, budaya terkait safety merupakan faktor penting untuk meningkatkan persepsi risiko keselamatan pekerja. Hasil dari telaah dokumen menjelaskan bahwa PT. X telah memiliki upaya membentu budaya keselamatan di seluruh proyek PT.
$\mathrm{X}$ melalui adanya komitmen $\mathrm{K} 3$ yang ditandatangani oleh manajemen, sertifikasi ISO 45001, sertifikasi Sistem Manajemen Keselamatan dan Kesehatan Kerja (SMK3) yang diimplementasikan menjadi program komunikasi seperti Toolbox meeting dan safety talk. Lebih rendahnya angka pekerja yang melihat kurangnya peran organisasi menandakan bahwa tetap diperlukan program refreshment untuk seluruh pekerja terkait dengan masalah organisasi.

\section{Analisis Hasil Distribusi Frekuensi Responden pada Faktor Voluntariness of Risk}

Hasil penelitian menjelaskan bahwa lebih banyak pekerja yang memiliki memiliki pandangan terpaksa sebanyak 66 (\%) dibandingkan yang sukarela (34\%). Tingginya akan keterpaksaan terkait risiko diperkuat dari hasil telaah dokumen dan observasi yang menggambarkan bahwa semakin tinggi pengalaman bekerja pekerja maka akan semakin tinggi perasaan sukarela untuk terbiasa bekerja dengan pekerjaan berisiko tinggi seperti bekerja di ketinggian dan pekerjaan panas. Tuntutan mandor saat bekerja untuk menyelesaikan target pekerjaan juga berpengaruh terhadap faktor keterpaksaan pekerja. Secara sadar, pekerja sudah mengetahui risiko yang ada namun dikarenakan proses pembayaran yang didasari oleh progress pekerjaan mengharuskan pekerja untuk menuntaskan pekerjaan dengan mengecualikan kaidah safety sesuai dengan prosedur yang telah diterapkan oleh manajemen. Faktor yang sering muncul dalam kasus unsafe act adalah pengambilan risiko secara sukarela. Individu merasa lebih nyaman dengan pengambilan risiko sukarela (Starr, 2020) karena mereka memegang kendali. Individu telah ditemukan lebih bersedia untuk menerima Voluntariness of Risk. Ini sangat terkait dengan faktor 'Control of Risk', di mana risiko yang lebih sedikit dikaitkan dengan situasi yang berada di bawah kendali pribadi (Sjoberg, 2004) 
Misalnya, dalam aspek risiko yang dapat dikendalikan, seorang manajer proyek atau pengambil keputusan dapat secara sukarela menerima risiko yang terkait dengan teknologi modern dalam konstruksi. Namun, faktor risiko ini dapat ditoleransi jika manfaat yang menguntungkan seperti akumulasi keahlian atau hasil keuangan yang menguntungkan memiliki kemungkinan untuk terjadi. Melalui perencanaan yang cermat dan pemanfaatan keahlian yang tersedia, manajer proyek atau pengambil keputusan seperti mandor dapat mengontrol pelaksanan pekerjaan dengan lebih baik (Onengiyeofori, 2018).

\section{Analisis Hasil Distribusi Frekuensi Responden pada Faktor Immediacy of Effect}

Hasil penelitian menjelaskan bahwa ada sebanyak $66 \%$ dari total pekerja merasa bahwa risiko yang ada tidak berdampak langsung dan hanya 34\% yang merasa bahwa risiko berdampak langsung pada pekerjaan. Tingginya pandangan terkait tidak adanya risiko berdampak langsung dapat diperkuat dari telaah dokumen yang menjelaskan bahwa selama 5 bulan proyek $\mathrm{Z}$ berjalan, belum pernah ada kecelakaan kerja, yang mencakup MTI, LTI, ataupun Fatality. Walaupun kejadian seperti near miss dan incident tetap ada. Hal ini disatu sisi menimbulkan kesan pada pekerja bahwa tidak akan ada dampak langsung yang besar dari kejadian-kejadian kecil yang terjadi di proyek. Data inspeksi menjelaskan bahwa bahwa pengendalian risiko dalam menilai risiko belum ditanamkan ke pekerja, seperti tidak adanya platform kerja untuk pekerjaan di ketinggian. Immediacy of effect telah ditemukan mempengaruhi penilaian risiko orang awam (Holmes, 1999). Arti yang berbeda dari pengendalian risiko yang berdampak langsung dan berkonsekuensi jangka panjang memiliki pendekatan yang berbeda dalam desain strategi pengendalian risiko. Risiko dikatakan serius dikarenakan immediacy of effect dari kemungkinan terjadinya dampak fatal pada sebuah kejadian (Lingard, 2005). Seperti pada kasus jatuh dari ketinggian, kebanyakan dari pekerja pasti telah memahami dan bisa membayangkan seperti apa skema ketika terjatuh dari ketinggian. Pada kenyataannya, hampir tidak mungkin untuk mengontrol batasan sumber daya dan hubungan kontraktual yang terjadi di sektor konstruksi, risiko terjatuh adalah dampak yang akan selalu diterima sebagai bagian dari risiko bekerja di sektor konstruksi

\section{Analisis Hasil Distribusi Frekuensi Responden pada Faktor Knowledge of Risk}

Hasil penelitian menunjukkan bahwa $75 \%$ dari pekerja memiliki pengetahuan kurang baik terkait risiko dan hanya $25 \%$ yang telah memiliki pengetahuan baik mengenai risiko. Hasil ini timbul dikarenakan bahwa pekerja tidak pernah dilibatkan dalam pembuatan dokumen prosedur keselamatan seperti Risk Control Self-Assessment (RCSA), dokumen ini merupakan dokumen awal identifikasi risiko terkait $\mathrm{K} 3$ yang mungkin timbul dari aktivitas proyek. Selain itu tersedia dokumen Hazard Identification and Determining Control (HIRADC), merupakan dokumen identifikasi risiko yang timbul pada suatu pekerjaan Hal ini menyebabkan kurangnya pengetahuan pekerja terhadap risiko, selain itu pengalaman juga membentuk pengalaman risiko terhadap suatu pekerjaan. Tool-box meeting (TBM) telah dilakukan setiap hari, namun kualitas dari topik pembahasan TBM masih belum baik, hal ini dapat dilihat dari tidak adanya pencatatan atau perencanaan topik yang akan disampaikan kepada pekerja pada saat TBM, sehingga pengetahuan terhadap risiko pekerja masih rendah. Pengetahuan tentang risiko di sektor konstruksi sangat membantu untuk menentukan akar penyebab risiko, respon efektif, interaksi antara risiko dan pemahaman yang baik tentang risiko di 
proyek. Ini juga dianggap sebagai alat yang ampuh untuk mengidentifikasi risiko, sehingga sering digunakan dalam proses identifikasi risiko (Baraka, 2019). Mayoritas pengetahuan tentang risiko didapatkan dari proyek-proyek yang dikerjakan. Situasi proyek menghasilkan pengetahuan baru yang dapat diterima untuk digunakan kembali di situasi lain (Maqsood, 2015). Oleh karena itu, penerapan manajemen pengetahuan risiko sangat menarik untuk diterapkan di sektor konstruksi (Carrillo dan Chinowsky, 2006), karena pendekatan ini dapat membantu industri untuk berinovasi, meningkatkan kinerja (Maqsood, 2015) dan untuk menangani karakteristik khusus pekerja dengan lebih baik.

\section{Analisis Hasil Distribusi Frekuensi Responden pada Faktor Control of Risk}

Hasil penelitian menunjukkan bahwa masih tingginya persentase kurangnya pemahaman terkait pengendalian risiko (79,5\%). Hal ini diperkuat dengan hasil analissi dokumen yang menjelaskan bahwa dalam program HSE telah tertulis bahwa terdapat program Komunikasi terkait pengendalian risiko seperti Toolbox meeting dan Safety Talk, dan juga sudah terdapat program inspeksi yang dilakukan secara rutin untuk memastikan risiko di lapangan telah terkendali. Faktor yang menyebabkan kurangnya pemahaman adalah pekerja belum memahami informasi yang disampaikan oleh staf proyek $\mathrm{Z}$ karena sifatnya hanya mendengarkan saja, tetapi forum tidak berjalan dua arah atau praktik, dengan forum yang berjalan dua arah dan praktik pekerja akan lebih memahami terkait pengendalian risiko, atau dapat dimungkinkan karena pengalaman pekerja yang tidak terbiasa bekerja secara aman karena didapati pekerja menggunakan APD ketika terdapat personil safety yang sedang melakukan inspeksi, bukan karena merasa butuh untuk memastikan pekerja bekerja secara aman. Karena itu diperlukan sebuah mekanisme perbaikan dalam bentuk sosialisasi dua arah dan pelatihan untuk mampu mengidentifikasi bahaya kerja dan mengendalikannya secara efektif. Sebuah studi juga menyebutkan bahwa peningkatan pengetahuan control of risk akan secara signifikan berpengaruh dalam memperbaiki faktor persepsi risiko lainnya di tempat kerja (Chaswa, 2020)

\section{Analisis Hasil Distribusi Frekuensi Responden pada Faktor Catastrophic Potential}

Hasil penelitian menunjukkan bahwa $68 \%$ pekerja melihat bahwa pekerjaan di proyek $\mathrm{Z}$ bersifat katastropik atau memiliki dampak terhadap kelompok dan hanya $32 \%$ pekerja yang melihat bahwa pekerjaan di proyek $\mathrm{Z}$ bersifat kronik. Dokumen RSCA menyebutkan bahwa proyek $\mathrm{Z}$ memiliki beberapa pekerjaan katastropik seperti pekerjaan pengangkatan baja yang memiliki risiko timbulnya korban lebih dari satu apabila terjadi kegagalan dalam proses pekerjaan tersebut. Walaupun lebih banyak pekerjaan di proyek $\mathrm{Z}$ yang bersifat kronik (seperti bekerja di ketinggian ataupun pekerjaan elektrikal) namun pekerja memiliki pandangan bahwa scope pekerjaan memiliki dampak yang besar ke pekerja lainnya. Faktor catastrophic potential memiliki jenjang yang berbeda dipandangan orang awam dan teknisi / expert, hal ini mengakibatkan mengakibatkan orang awam memberikan bobot yang relatif kecil untuk penilaian risiko yang dilakukan oleh teknisi Schmidt, 2004).

\section{Analisis Hasil Distribusi Frekuensi Responden pada Faktor Common Dread}

Hasil penelitian menunjukkan bahwa ada sebanyak $73 \%$ pekerja yang tidak takut terhadap dampak dari risiko pekerjaan dan hanya $37 \%$ pekerja yang memiliki 
ketakutan dari dampak risiko pekerjaan yang dilakukan. Dokumen RSCA menjelaskan bahwa beberapa beberapa pekerjaan yang memiliki risiko hingga menyebabkan fatality, namun data inspeksi yang dilakukan oleh tim proyek $\mathrm{Z}$ menunjukan masih banyak kondisi bahaya yang belum dilakukan pengendalian. Namun karena kurangnya kurangnya persepsi rasa takut terhadap kondisi bahaya, sehingga sudah terbiasa dengan kondisi yang tidak aman, sekalipun kondisi tersebut memiliki risiko yang dapat menyebabkan fatality. Faktor common dread memiliki pengaruh paling besar dalam studi Chaswa (2020) yakni sebesar $16,21 \%$ dari total varians yang dibandingkan dengan faktor-faktor lain. Pada paradigma risk perceived, faktor common dread terjadi karena orang memperkirakan frekuensi suatu risiko dengan mengingat kejadian-kejadian dari lingkaran sosial atau media mereka, mereka mungkin menilai terlalu tinggi risiko yang relatif jarang tetapi besar karena kehadirannya yang berlebihan dan seringnya meremehkan risiko yang kurang besar (Lichtenstein et al, 1980).

\section{Analisis Hasil Distribusi Frekuensi Responden pada Faktor Severity of Consequences}

Hasil penelitian menunjukkan bahwa ada sebanyak $57 \%$ pekerja yang melihat bahwa risiko pekerjaan tidaklah fatal dan ada sebanyak $43 \%$ pekerja yang melihat pekerjaan memiliki risiko yang fatal. Secara statistik tidak terlalu banyak ketimpangan soal pandangan terkait keparahan dampak. Namun kecondongan pekerja melihat pekerjaan tidaklah fatal dapat dijelaskan dari hasil analisis dokumen yang mencatat bahwa proyek $\mathrm{Z}$ memiliki risiko pekerjaan yang dapat menyebabkan fatality. Namun, selama proyek ini berjalan belum ada catatan terkait kecelakaan kerja, medical treatment injury, lost time injury, atau fatality yang terjadi. Sehingga, karena pekerja belum pernah mengalami atau melihat kejadian seperti kecelakaan kerja. Maka pekerja melihat bahwa risiko pekerjaan yang mereka lakukan tidaklah fatal. Faktor severity of consequences dilihat sebagai faktor yang melihat dampak sebagai acuan pekerja dalam melihat risiko. Studi mengenai severity of consequences secara umum dijelaskan oleh Wilson (2018) dalam studinya yang menganalisis persepsi risiko secara umum dimana ketika konsekuensi yang dapat dibayangkan secara langsung seperti kasus cuaca ekstrem, kehancuran reactor nuklir akan mengakibatkan sudut pandang kita terkait severity of consequences semakin tinggi. Sebaliknya, jika dampak yang dapat dibayangkan tidak langsung seperti merokok ataupun perubahan iklim maka sudut pandang akan menjadi semakin rendah (McCright \& Dunlap, 2011). Di sektor konstruksi sendiri dapat dikatakan bahwa fatality dapat menjadi pelajaran contoh untuk melihat dampak dari kesalahan pemakaian body harness dalam bekerja di ketinggian dibandingkan rutinitas memakai APD untuk mencegah terjadinya perilaku berisiko yang mengakibatkan kematian (Chaswa, 2020).

\section{Diagram Jaring Faktor yang Membentuk Persepsi Risiko Keselamatan}

Hasil penelitian ini menunjukkan bahwa masing-masing faktor yang membentuk persepsi risiko keselamatan pekerja di proyek Z PT. X masih rendah, sehingga perlu ditingkatkan agar dapat membentuk persepsi risiko yang baik. Berdasarkan Grafik 1, berikut adalah faktor yang menjadi prioritas untuk perbaikan yang dapat dilakukan oleh pekerja proyek $\mathrm{Z}$ 


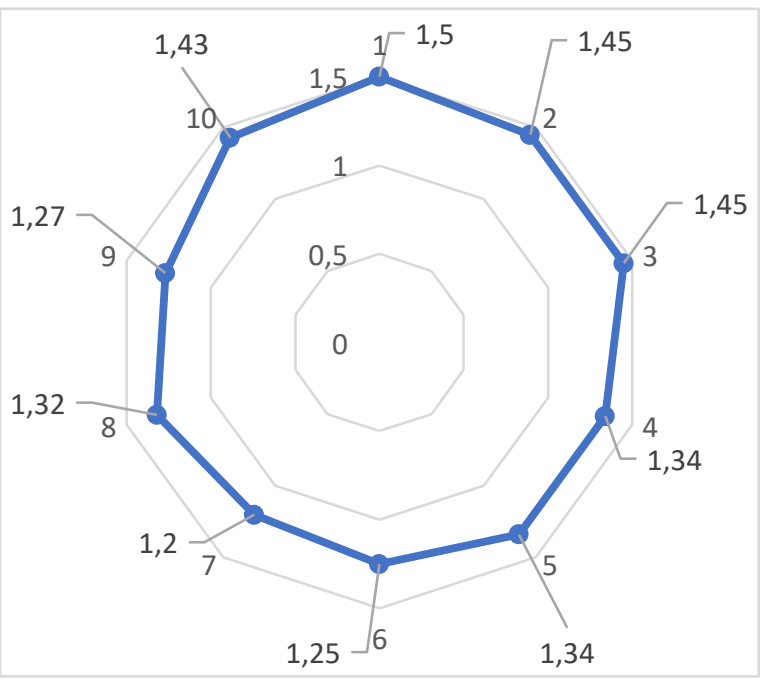

\section{Grafik 1. Diagram Faktor Persepsi Risiko Keselamatan Pekerja}

Secara garis besar seluruh faktor memiliki skala yang tidak jauh berbeda secara gap namun bisa dikatakan cukup rendah dibawah standar. Faktor control of risk dari dimensi risk perceived menjadi perhatian dikarenakan memiliki poin terkecil dengan nilai 1,2 dari skala 2 . Adapun faktor knowledge of risk dan common dread memiliki skala yang kurang lebih sama dengan control of risk. Sedangkan untuk dimensi sosial budaya, faktor regulatory dan organization memiliki skala terendah dengan nilai 1,45 dari skala maksimal 2. Namun kedua faktor ini, masih cenderung lebih baik dibandingkan faktor-faktor dimensi risk perceived.

\section{KESIMPULAN}

Berdasarkan hasil penelitian ini telah didapatkan gambaran faktor-faktor yang membentuk persepsi risiko keselamatan pekerja di proyek Z PT. X, masing-masing faktor masih menunjukan nilai yang kurang baik dalam membentuk persepsi risiko. Hal yang menjadi perhatian adalah seluruh faktor-faktor dalam dimensi risk perceived memiliki persentase kurang baik lebih dari 50\%. Hal ini berbeda dibandingkan persepsi risiko keselamatan pekerja dari dimensi sosial dan budaya yang cenderung seimbang atau memiliki ketimpangan yang sedikit. Sehingga dapat dikatakan bahwa pekerja masih belum memiliki pandangan yang concern terkait risiko keselamatan dari segi aspek pemahaman individu. Faktor knowledge of risk, control of risk, dan common dread menjadi prioritas utama dikarenakan ketiga faktor ini memiliki nilai kurang baik lebih dari $70 \%$ dari jumlah pekerja yang mengisi kuesioner. Saran yang diberikan pada manajemen proyek $\mathrm{Z}$ adalah dapat memperhatikan rekomendasi prioritas berdasarkan hasil analisis yang telah dijelaskan pada masing-masing faktor dengan mempertimbangkan dimensi risk perceived sebagai fokus perbaikan dengan faktor knowledge of risk, control of risk, dan common dread. Harapannya, perbaikan tersebut akan membentuk persepsi risiko keselamatan pekerja dengan lebih baik dan mencegah terjadinya kemungkinan kejadian tidak aman di tempat kerja.

\section{UCAPAN TERIMA KASIH}

Peneliti mengucapkan terima kasih kepada rekan-rekan Proyek X PT. Z, pembimbing dan teman-teman yang telah membantu berjalannya proses pengambilan data serta penyusunan penelitian ini.

\section{DAFTAR PUSTAKA}

Alomari, K. A., Gambatese, J. A., \& Tymvios, N. (2018). Risk Perception Comparison among Construction Safety Professionals: Delphi Perspective. Journal of Construction Engineering and Management, 144(12), 04018107. https://doi.org/10.1061/(asce)co.1943 $-7862.0001565$

Badan Pusat Statistik Republik Indonesia (2020) 'Ekonomi Indonesia 2019 Tumbuh 5,02 Persen', Badan Pusat Statistik, (17/02/Th. XXIV), pp. 1-12. Available 
at: https://www.bps.go.id/pressreleas e/2020/02/05/1755/ekonomiindonesia-2019-tumbuh-5-02persen.html.

Baraka, H. (2019). Risk in The Construction Industry. Current Trends in Civil \& Structural Engineering, 2(4), 4-6. https://doi.org/10.33552/ctcse.2019.0 2.000541

Carrillo, P., \& Chinowsky, P. (2006). Exploiting knowledge management: the engineering and construction perspective.

https://repository.lboro.ac.uk/articles/j ournal_contribution/Exploiting_know ledge_management_the_engineering and_construction_perspective/944995 4

Chaswa, E. N., Kosamu, I. B. M., Kumwenda, S., \& Utembe, W. (2020). Risk perception and its influencing factors among construction workers in Malawi. Safety, 6(2), 1-12. https://doi.org/10.3390/safety6020033

Habibnezhad, M., Fardhosseini, S., Vahed, A. M., Esmaeili, B., \& Dodd, M. D. (2016). The Relationship between Construction Workers' Risk Perception and Eye Movement in Hazard Identification. Construction Research Congress 2016: Old and New Construction Technologies Converge in Historic San Juan Proceedings of the 2016 Construction Research Congress, CRC 2016, April 2018, 2984-2994. https://doi.org/10.1061/97807844798 27.297

Holmes, N., Lingard, H., Yesilyurt, Z., \& De Munk, F. (1999). An Exploratory Study of Meanings of Risk Control for Long Term and Acute Effect Occupational Health and Safety Risks in Small Business Construction Firms. Journal of Safety Research, 30(4), 251-261. https://doi.org/10.1016/S00224375(99)00020-1
Lewis, Y. (2003). The self as a moral concept. British Journal of Social Psychology, 42(2), 225-237. https://doi.org/https://doi.org/10.1348 /014466603322127229

Lichtenstein, S., \& Fischhoff, B. (1980). Training for calibration. Organizational Behavior and Human Performance, 26(2), 149-171. https://doi.org/https://doi.org/10.1016 /0030-5073(80)90052-5

Lingard, H., \& Rowlinson, S. M. (2005). Occupational Health and Safety in Construction Project Management. Spon Press. https://books.google.co.id/books?id= Pu8Abt1vsPQC

Loewenstein, G. F., Weber, E. U., Hsee, C. K., \& Welch, N. (2001). Risk as feelings. In Psychological Bulletin (Vol. 127, Issue 2, pp. 267-286). American Psychological Association. https://doi.org/10.1037/00332909.127.2.267

Man, S. S., Chan, A. H. S., \& Alabdulkarim, S. (2019). Quantification of risk perception: Development and validation of the construction worker risk perception (CoWoRP) scale. Journal of Safety Research, 71, 25-39. https://doi.org/10.1016/j.jsr.2019.09.0 09

Maqsood, T. (2015). The Role of Knowledge Management in Supporting Innovation and Learning in Construction The Role of Knowledge Management in Supporting Innovation and Learning in Construction A thesis submitted in fulfilment of the requirements for the degree of Doctor of . January 2006.

Martin, H., \& Lewis, T. M. (2014). Pinpointing Safety Leadership Factors for Safe Construction Sites in Trinidad and Tobago. Journal of Construction Engineering and Management, 140(2), 04013046. https://doi.org/10.1061/(asce)co.1943 $-7862.0000795$ 
McGonagle, A. K., \& Kath, L. M. (2010). Work-safety tension, perceived risk, and worker injuries: A mesomediational model. Journal of Safety Research, 41(6), 475-479. https://doi.org/10.1016/j.jsr.2010.09.0 02

Namian, M., Albert, A., Zuluaga, C. M., \& Behm, M. (2016). Role of Safety Training: Impact on Hazard Recognition and Safety Risk Perception. Journal of Construction Engineering and Management, 142(12), 04016073. https://doi.org/10.1061/(asce)co.1943 $-7862.0001198$

Oswald, D., Sherratt, F., \& Smith, S. (2014). Risk Perception and Safety Behaviour: An ethnographic study. Achieving Sustainable Construction Health and Safety, JUNE 2014.

Schmidt, M. R. (2004). Investigating Risk Perception: A Short Introduction. Loss of Agro-Biodiversity in Vavilov Centers, with a Special Focus on the Risks of Genetically Modified Organisms GMOs, October, 1-16. http://www.markusschmidt.eu/pdf/Int ro_risk_perception_Schmidt.pdf

Serpella, A. F., Ferrada, X., Howard, R., \& Rubio, L. (2014). Risk Management in Construction Projects: A Knowledge-based Approach. Procedia - Social and Behavioral Sciences, 119, 653-662. https://doi.org/10.1016/j.sbspro.2014. 03.073

Shin, M., Lee, H. S., Park, M., Moon, M., \& Han, S. (2014). A system dynamics approach for modeling construction workers' safety attitudes and behaviors. Accident Analysis and Prevention, 68, 95-105. https://doi.org/10.1016/j.aap.2013.09. 019

Sjöberg, L., Moen, E., \& Rundmo, T. (2004). of the psychometric Explaining risk. In An evaluation of the psychometric paradigm in risk perception research (Vol. 2, Issue 2). http://66.102.9.104/search?q=cache: $x$ 8G44WOi3ssJ:www.svt.ntnu.no/psy/ Torbjorn.Rundmo/Psychometric_para digm.pdf+Explaining+risk+perceptio n. \&hl=en $\& \mathrm{ct}=\mathrm{clnk} \& \mathrm{~cd}=3 \& \mathrm{gl}=\mathrm{uk}$

Slovic, P., Fischhoff, B., \& Lichtenstein, S. (1980). Judgmental Biases in Risk Perceptions. Perceived Risk: Psychological Factors and Social Implications, 1-13.

Slovic, P., \& Weber, E. U. (2002). Perception of risk posed by extreme events. Risk Management Strategies in an Uncertain World, 1-21.

Starr, C. (2020). Social Benefit Versus Technological Risk: What is Our Society Willing to Pay for Safety? Renewable Energy, 165, 136-152. https://doi.org/10.4324/97813157932 45-125

Suparno et al (2019). Implementasi manajemen risiko dalam pelaksanaan proyek konstruksi bagi para konsultan dan kontraktor

Wilson, R. S., Zwickle, A., \& Walpole, H. (2019). Developing a Broadly Applicable Measure of Risk Perception. Risk Analysis, 39(4), 777791.

https://doi.org/10.1111/risa.13207 